\title{
MENGAJAR DI TPA \\ TPA AR-RAHMAN
}

\author{
Amelia Weni \\ NIM: 19183770410386 \\ Email: ameliaweni028@gmail.com
}

\section{Bentuk Kegiatan}

Mengajar di TPA Ar-

Rahman

\section{Lokasi}

Desa Balangloe Tarowang

Dusun Balangloe

\section{Hari/Tanggal}

dan

\section{Waktu}

Senin, 28 September 2020

Jam 15:30- Selesai

4.Peserta yang Dilibatkan

Mahasiswa

KKLP,

Ustadz, Ustadza dan

Anak-anak Santri

\section{Alasan Diadakannya}

Ingin bergabung dengan anak-anak santri dan berbagi ilmu

\section{Tujuan dan Manfaat} Saling berbagi ilmu, mengajar sambil belajar $\backslash$

\section{Produk Kegiatan}

Iqra dan Al-Quran

\section{Deskripsi Kegiatan}

Setelah sholat ashar di hari senin, saya dan teman-teman menuju ke TPA Ar-Rahman untuk bergabung dengan adikadek santri, belajar mengaji dan membaca doa-doa harian. 


\section{Referensi Wajib}

- HeRIANTO, H., \& Amir, A. S. (2020, September 10). Pedoman Pelaksanaan Kuliah Kerja Lapangan Plus (KKLP) Mahasiswa STIE dan STKIP YAPTI Jeneponto. https://doi.org/10.31219/osf.io/7dvpk 